\title{
Reducing Unavoidable Nutrient Losses from Florida's Horticultural Crops
}

\author{
S. Shukla ${ }^{1,6}$, B.J. Boman ${ }^{2}$, R.C. Ebel ${ }^{3}$, P.D. Roberts ${ }^{4}$, \\ and E.A. Hanlon ${ }^{5}$
}

ADDITIONAL INDEX WORDs. best management practices, drainage, stormwater, tailwater reuse, nitrogen, phosphorus

\begin{abstract}
Summary. Despite efforts to optimize water and nutrient inputs to Florida's vegetable and fruit crops, the sandy soils, shallow water table, and tropical climate of Florida result in nutrient leaching losses that are unavoidable. Water quantity and quality management strategies that can reduce these nutrient losses from Florida's horticultural crops were reviewed and research needs for quantifying their effectiveness were identified. The water quantity management strategies included water table management for irrigation, drainage management, detention of runoff and drainage, and summer flooding. In addition to the expected water quality benefits of these practices, potential effects on crop production and farm economics were also discussed. Watershed-scale adoption of stormwater harvesting has the potential to not only reduce the nutrient loadings but also become a source of additional income for landowners through water trading. The water quality practices included structural and managerial practices (e.g., vegetative filter strips and ditch cleaning). Key research needs for reducing the unavoidable nutrient discharges included the development of a crop-specific drainage management tool; quantification of farm and watershed-scale benefits of stormwater detention and its reuse with regards to nutrient loadings, water supply, crop production, and farm income; enhancement of hydraulic efficiency of detention areas; and effects of summer flooding and ditch maintenance and cleaning on nutrient discharges.
\end{abstract}

$\mathrm{N}$ utrient loading from agricultural and urban areas is one of the main causes of the degradation of Florida water bodies. A large portion of the nutrient loading to surface and groundwaters of Florida originates from commercial horticultural crop production. Although numerous horticultural crops are grown in Florida, citrus (Citrus spp.) and vegetables [includes watermelon (Citrullus lanatus)] are the

We appreciate the financial assistance of Florida Agricultural Experiment Station for publication of this manuscript.

We acknowledge Ms. Asmita Shukla for her help in manuscript preparation. Thanks are due to Mr. James M. Knowles for his help in preparing Figure 1 .

${ }^{1}$ Associate Professor, Agricultural and Biological Engineering Department, Southwest Florida Research and Education Center, University of Florida, Immokalee, FL 34142

${ }^{2}$ Professor, Agricultural and Biological Engineering Department, Indian River Research and Education Center, University of Florida, Ft. Pierce, FL 34945

${ }^{3}$ Associate Professor, Horticultural Science Department, Southwest Florida Research and Education Center, University of Florida, Immokalee, FL 34142

${ }^{4}$ Associate Professor, Plant Pathology Department, Southwest Florida Research and Education Center, University of Florida, Immokalee, FL 34142

${ }^{5}$ Professor, Soil and Water Science Department, Southwest Florida Research and Education Center, University of Florida, Immokalee, FL 34142

${ }^{6}$ Corresponding author. E-mail: sshukla@ufl.edu. main crops with regard to acreage [U.S. Department of Agriculture (USDA), 2007] and water quality effects.

A wide array of best management practices (BMPs) has been recommended to reduce nutrient loading from agricultural areas. These BMPs differ with regard to water quality effects, ease of implementation, cost, and acceptability to the landowner. A large percentage of the BMPs are targeted at reducing the leaching of nutrients from the root zone by improved irrigation and fertilizer management practices or simply retaining applied nutrients in the root zone. However, despite efforts to optimize water and nutrient input of crops, considerable nutrient leaching is still likely due to highly permeable sandy soils, shallow root zones, and high intensity rain storms. Therefore, other
BMPs are designed to better manage the nutrients that are lost through the root zone to achieve water quality and conservation goals. These losses are greatly increased after high rainfall events. It should be noted that nutrient movement within and below the root zone is a continuous process, and depending on the antecedent moisture conditions, even a small rainfall can result in extending the solute spread beyond the root zone. To reduce the amount of nutrients discharged from a farm to the receiving water body, a systems approach is needed that includes reductions in the drainage and runoff flow volumes and associated nutrient mass from production fields to the farm outlet. Examples of these approaches vary from reducing drainage volume to the retention, detention, and recycling of stormwater. The goal of this article is to review these practices and their effectiveness, and to identify knowledge gaps for Florida. Toward this goal, we first describe the climatic, physiographic, and hydrologic differences among Florida's main horticultural crop producing regions followed by a discussion on the water quantity and quality management strategies that can reduce the runoff and drainage nutrient losses. Water quantity practices include controlling, detaining, and reusing the drainage and runoff, while water quality practices include using vegetative filter strips (VFS) and drainage ditch management. Potential barriers to implementation of these BMPs such as the spread of disease due to water reuse are also discussed. This article addresses the management of nutrients that have already leached below the root zone and does not cover the BMPs that address the control of nutrient inputs such as use of soil testing for designing the nutrient management program and use of controlled release fertilizer. These BMPs are covered in other articles that are part of this special volume.

\begin{tabular}{llll}
\hline $\begin{array}{l}\text { Units } \\
\begin{array}{l}\text { To convert U.S. to SI, } \\
\text { multiply by }\end{array}\end{array}$ & U.S. unit & SI unit & $\begin{array}{l}\text { To convert SI to U.S., } \\
\text { multiply by }\end{array}$ \\
\hline 0.4047 & acre $(\mathrm{s})$ & $\mathrm{ha}$ & 2.4711 \\
0.3048 & $\mathrm{ft}$ & $\mathrm{m}$ & 3.2808 \\
2.54 & inch $(\mathrm{es})$ & $\mathrm{cm}$ & 0.3937 \\
25.4 & inch $(\mathrm{es})$ & $\mathrm{mm}$ & 0.0394 \\
$\left({ }^{\circ} \mathrm{F}-32\right) \div 1.8$ & ${ }^{\circ} \mathrm{F}$ & ${ }^{\circ} \mathrm{C}$ & $\left(1.8 \times{ }^{\circ} \mathrm{C}\right)+32$
\end{tabular}




\section{Florida's horticultural crop production regions}

Fresh fruit and vegetables are the leading agricultural commodities of Florida and accounted for $45 \%$ of the state's agricultural receipts in 2000 (Stevens et al., 2003). Nationally, Florida is ranked first in citrus production and second in total vegetable production (Stevens et al., 2003). Such large production of horticultural crops is facilitated by abundant rainfall and a subtropical climate. The production regions for Florida's horticultural crops cover the entire peninsula from north to south (Fig. 1). The acreage of these crops varies in the different production regions, mainly due to the risk of extreme climatic events such as freezes. The temperatures for the three climatic zones, north, central, and south, range from cooler (minimum $=14.4^{\circ} \mathrm{C}$, maximum $=26.7^{\circ} \mathrm{C}$ ) in the northern zone to warmer $\left(\right.$ minimum $=18.9^{\circ} \mathrm{C}$, maximum $=29.4^{\circ} \mathrm{C}$ ) in the southern region, with southern Florida described as hot-humid (Black, 2003; Winsberg, 2003). Most citrus is produced in the southern two-thirds of the state due to the low probability of freeze (Hodges et al., 2006). Although vegetable crops are grown throughout the state, southern Florida (numbers 13-31; Fig. 1) accounts for almost $85 \%$ of the state's vegetable acreage (156,000 acres) (USDA, 2002).

Apart from temperature variations, there also exists differential rainfall. The average annual rainfall in the citrus- and vegetable-growing regions of the state (excluding Key West, Fig. 1) ranges from $1750 \mathrm{~mm}$ in the panhandle to $1120 \mathrm{~mm}$ in parts of southeastern and central Florida (Henry, 1998). Average rainfall for southern Florida is $1370 \mathrm{~mm}$ (VanArman et al., 1998 ), of which $\approx 70 \%$ falls during the wet period (June-October). A large proportion of rainfall in Florida results from tropical storms and hurricanes, which produce high rainfall volumes in a short time period. The

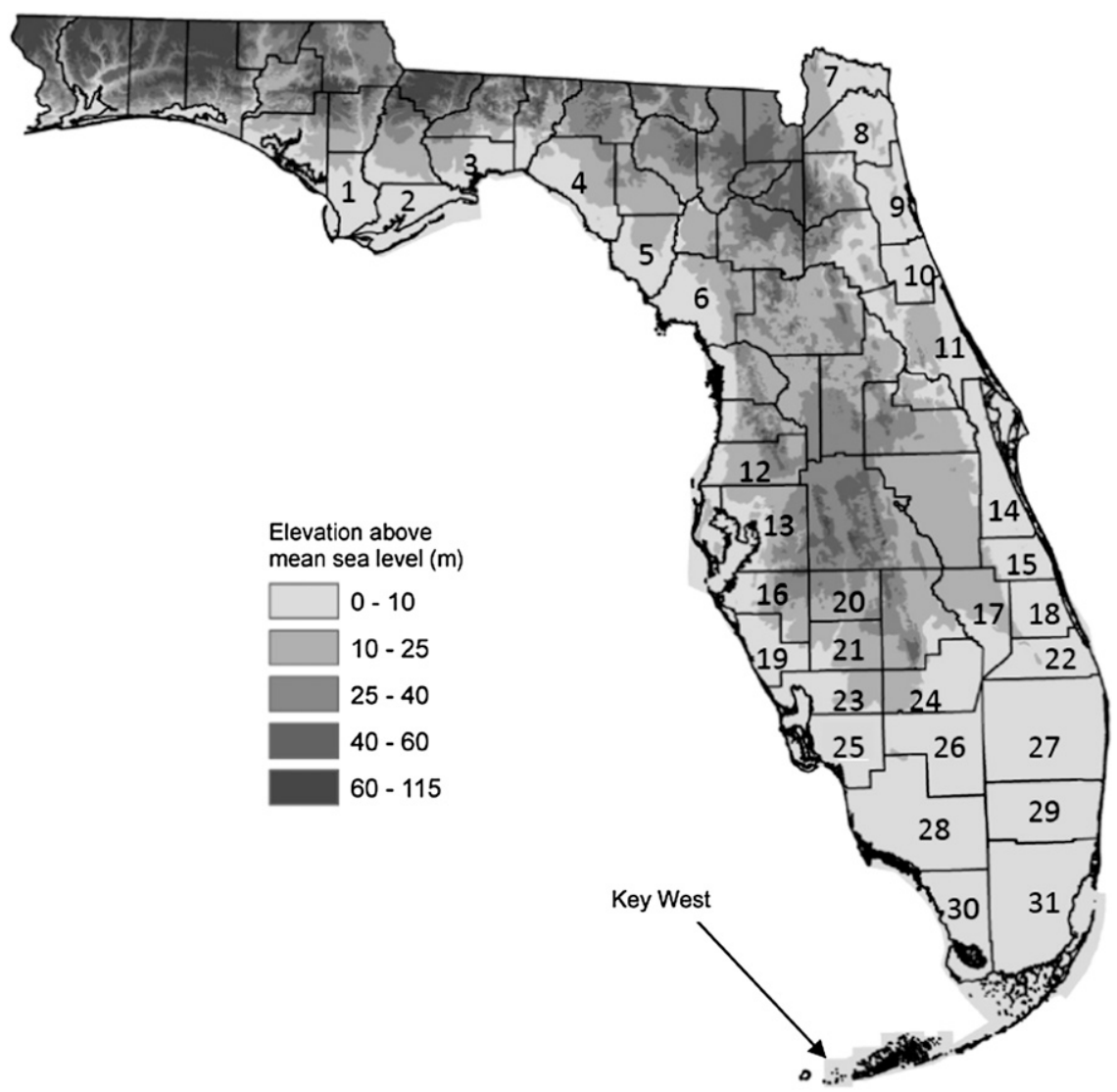

Fig. 1. Topography and major vegetable growing counties of Florida. The numbers 1 through 31 identify major vegetable-producing counties that have shallow water table conditions. Data from Berndt et al., (1998) were used to determine general water table depths in Florida $(1 \mathrm{~m}=3.2808 \mathrm{ft})$.

year-to-year variation of daily maximum recorded rainfall for southern Florida is 100 to $460 \mathrm{~mm}$ (Pathak, 2001). Most of these events occur during the August through October period. The high-intensity rainfall events result in saturation of soils, leaching of nutrients, and large flows to lakes, rivers, and estuaries from the drainage required to protect agricultural crops.

Although nutrient leaching after high rainfall events occurs from all horticultural crops, there are differences in the amount of nutrient leaching between fruit and vegetable crops. The potential nutrient leaching losses are especially large for vegetable crops because most of the beds are prepared in August and September. For bed preparation, high soil moisture is needed. In most of southern Florida, this requirement is achieved by artificially raising the water table to $\approx 8$ inches from the soil surface. Raising the water table is achieved by pumping water into the perimeter as well as field ditches. Transplanting occurs 3 to 4 weeks after beds covered with plastic mulch are prepared. Plastic mulch has several benefits such as reduced weed growth and fertilizer leaching from the bed. The combination of low plant uptake, unusually high water table, and frequent high rainfall events during August through October results in a higher potential for nutrient [nitrogen $(\mathrm{N})$, phosphorus $(\mathrm{P})$, and potassium $(\mathrm{K})$ ] leaching than later in the growing season. Planting the second crop of vegetables in central and southern Florida normally occurs in February through March. Although the likelihood of large rainfall events (e.g., 3 inches in $3 \mathrm{~d}$ ) is less during this period, they do occur and can cause extensive leaching. For Florida vegetable production systems, a total rainfall of 3 inches in $3 \mathrm{~d}$ is considered a leaching rain and growers are advised to add additional $\mathrm{N}$ and K after such a rainfall to replace the nutrients leached. In a study to evaluate irrigation and nutrient BMPs in southwestern Florida for tomato (Solanum lycopersicum) and watermelon crops, Hendricks et al. (2007) reported that wet spring conditions can result in extensive leaching of nutrients and cause reduction in crop yield. They noted that several rainfall events, especially between bed preparation and transplanting, were the most important drivers for nutrient leaching. 
Considerable topographic variability exists among the state's vegetable and fruit production areas that results in considerable differences in hydrology when combined with variability in rainfall and soils. Although most of the soils in the state are sandy, surface and groundwater flows can vary from location to location. Flat topography, high water table, and highly conductive soils exist in coastal areas of northern Florida and almost all of southern Florida (Fig. 1). These conditions usually generate runoff when the entire soil profile becomes saturated (i.e., the water table reaches the soil surface). Relatively higher elevations and consequently deeper water table in the central Florida ridge region result in extensive infiltration that reduces the runoff potential. The central Florida ridge is a north-southoriented sandy uplands in the center of the state (i.e., areas of higher elevation shown in Fig. 1). A large fraction of the surface water flows in southern Florida are derived from artificial drainage of low-lying areas that is necessary for agriculture and urban development. As recently as 100 years ago, most of Florida and especially southern Florida were composed of extensive marsh or swamps (VanArman et al., 1998). Runoff among Florida's horticultural crop producing regions varies considerably. Runoff generated from most of the southern Florida and the central Florida ridge is $25 \mathrm{~cm}$ per year, 25 to $50 \mathrm{~cm}$ from most of the northeastern coastal plain and south-central coastal plain, and more than $50 \mathrm{~cm}$ from most of the panhandle (Mossa, 1998). Because most areas of southern Florida are poorly drained, nearly all the citrus and vegetable fields in these areas have ditches to drain the fields after rainfall events. Most of the surface flows in agricultural areas of southern Florida are derived from such drainage.

Moderating the rate of drainage, water retention, and reuse combined with practices that directly target water quality (e.g., VFS and canal cleaning) can provide opportunities for reducing water and nutrient discharges, especially after high rainfall events. Strategies include water table management to optimize rainfall storage in the root zone, capturing and storing runoff water in the drainage ditches, temporary detention of runoff and drainage, reuse of the drainage and runoff (also termed as tailwater recovery and reuse), and treatment of runoff and drainage before discharging to downstream water bodies. Although water quantity and quality are related, these strategies can be divided into water quantity, including management and reuse, and quality.

\section{Managing water quantity}

In this discussion, water quantity (or volume management) refers to all water management practices used in the production and management of horticultural crops that can help increase the residence time of water within the farm before it is discharged to the downstream water bodies. These practices range from water table management to water storage optimization (on-site retention) to detention/retention in conveyance and storage structures.

\section{Water table management}

WATER TABLE MANAGEMENT FOR IRRIGATION. Water table management for irrigation is mostly applicable to seepage irrigation systems that involve artificially raising the water table sufficiently high to provide adequate soil moisture in the crop root zone. Seepage irrigation is used in high water table areas of Florida, which include most of southern Florida and the east coast of Florida for sod, vegetable, ornamental crops, and citrus production.

Traditionally, producers have used past experience to adjust water table levels, often resulting in excessive irrigation. Even though the target water table growers generally use for vegetables in southern Florida is 40 to $45 \mathrm{~cm}$, Stanley and Clark (2003) found that there was no advantage to maintaining a water table higher than $60 \mathrm{~cm}$. If the water table is elevated by excess irrigation or rainfall event, successive irrigation can be delayed for several days until the water table subsides to a level where it can no longer supply sufficient water to meet the crop needs.

Soil moisture measurement devices can be used to determine the depth of the water table that will provide optimum soil moisture in the crop root zone. In a study on seepage irrigated vegetable crops in southwestern Florida, Pandey et al.
(2007) compared a soil moisturebased water table management (SMWM) system with the traditional practice of management based on experience. The two systems were evaluated for water use, runoff, groundwater $\mathrm{P}$ concentration, and crop yield. Water use for the study was defined as water delivered to the field minus drainage losses. Their study found that: 1) SMWM can help lower the water table by $13 \mathrm{~cm}$ and decrease water use by $36 \% ; 2$ ) SMWM can reduce the number of runoff events by $50 \%$; 3 ) SMWM resulted in higher $\mathrm{P}$ concentrations in the shallow groundwater than the traditional method; and 4) the SMWM had equal or higher yield than the traditional method. The higher concentration of $\mathrm{P}$ in SMWM was due to dilution of $\mathrm{P}$ in the soil solution by the extra volume of water in the traditional method. Although the effects of SMWM on groundwater quality were evaluated, the effects on actual $\mathrm{N}$ and $\mathrm{P}$ loading from runoff and drainage were not evaluated. The higher yield for the SMWM was due to the waterborne plant disease caused by Phytophthora capsici on the traditional side. This disease is mainly caused by excess water in the soil. Although soil moisture monitoring is recommended to determine the optimum water table depth at individual farms, simple water table monitoring wells can also be used to manage seepage irrigation especially, if the soil-specific optimum water table depth is determined.

Reduced runoff was also observed for citrus in a modeling study by Boman and Wilson (2003), which found that improved water table management has the potential to reduce runoff volume from citrus groves. Studies conducted on citrus water table management have indicated a range of optimum water table depths for different soils. In a study on capillary rise in two fine sandy soils in southern Florida, Calvert et al. (1967) found that capillary rise was between 15 and $30 \mathrm{~cm}$ above the free water surface. Obreza and Boman (1992) evaluated the maximum groundwater depth that could fully supply citrus water requirements for three southern Florida soils. Water table depths in the range of 50 to $75 \mathrm{~cm}$ were adequate to maintain sufficient moisture in the root zone 
so that evapotranspiration was not limited.

Managing the water table for irrigation using the data available for citrus and vegetables for specific soils has the potential to conserve water as well as reduce runoff and drainage from the citrus and vegetable farms. Reduction in drainage and runoff volume is likely to reduce nutrient loadings from the farm. The optimum water table for different soils can be set based on the literature data for some soils or the use of soil moisture measurement in the root zone. Soil moisture measurement is the preferred strategy using actual field soil moisture levels to adjust the water table to provide optimum moisture in the root zone. Although some studies have been conducted to evaluate the benefits of water table management for irrigation on runoff and water savings, limited information is available to quantify the reduction in $\mathrm{N}$ and $\mathrm{P}$ loadings in Florida.

WATER TABLE MANAGEMENT FOR DRAINAGE. Drainage should be managed to avoid adverse impacts on the crop, reduce erosion, and help mitigate negative effects on surface water and groundwater quality. Controlled drainage can conserve water and maintain optimum soil moisture to: 1) store rainfall in the soil for more efficient crop production; 2) improve surface water quality by reducing total outflow from the field (Evans et al.,1996); 3 ) reduce nitrates $\left(\mathrm{NO}_{3}{ }^{-}\right.$ $\mathrm{N})$ in the drainage water by enhancing conditions for denitrification; 4) enhance soil $\mathrm{P}$ retention through adsorption (Harris et al., 1996); 5) reduce subsidence and wind erosion of organic soils in southern Florida; and 6) provide water and habitat for wildlife, especially waterfowl. With controlled drainage, a water control structure on the drain or ditch allows the drainage outlet elevation to be set at a desired level. Flashboard structures are typically used and they may be manually operated or automated to adjust outlet elevation in response to rainfall. Controlled drainage tends to decrease $\mathrm{P}$ concentrations on predominately surface systems, but has the opposite effect on predominantly subsurface systems (Evans et al., 1996).

Drainage water management has the potential to reduce $\mathrm{NO}_{3}-\mathrm{N}$ loads from subsurface drainage systems by $30 \%$ to $40 \%$, mainly by reducing drainage outflow volumes (Cooke et al., 2005). With less water leaving the field through the drainage system, there is potentially less $\mathrm{NO}_{3}-\mathrm{N}$ flowing out of the drainage system, even with no change in $\mathrm{NO}_{3}-\mathrm{N}$ concentration. In a summary of 14 North Carolina field studies, Evans et al. (1996) reported that controlled drainage reduced annual transport of total $\mathrm{N}$ and total Kjehldal N (TKN) by $45 \%$ at the field edge and total P by $35 \%$. Controlled drainage had little effect on the concentrations of $\mathrm{N}$ and $\mathrm{P}$ in the outflow, therefore the reductions were primarily from reduced outflow volume from the fields.

Several studies from North Carolina have investigated the effectiveness of controlled drainage (Doty et al., 1985; Gilliam et al., 1978), developed design guidelines (Evans and Skaggs, 1989; Gilliam and Skaggs, 1986), and demonstrated application of the method (Evans et al., 1990, 2000). Others document the effect of drainage on $\mathrm{N}$ loss (Burchell et al., 2005; Gilliam and Skaggs, 1986; Skaggs and Chescheir, 2003; Skaggs and Gilliam, 1981). Researchers have reported reductions in $\mathrm{NO}_{3}-\mathrm{N}$ loads due to drainage water management ranging from $14 \%$ (Liaghat and Prasher, 1997) to $87 \%$ (Gilliam et al., 1979).

In a 3-year experiment in Iowa, Kalita and Kanwar (1993) examined the effect of outlet level on crop yield and $\mathrm{N}$ concentration in a controlled drainage system. They observed a reduction in $\mathrm{NO}_{3}-\mathrm{N}$ concentration for all outlet levels and an increase in crop yield for most. They also found, however, that setting the outlet too close to the soil surface during the growing season can reduce yields. Drury et al. (1996) reported a $25 \%$ decrease in mean $\mathrm{NO}_{3}-\mathrm{N}$ concentration and a $49 \%$ decrease in the total annual $\mathrm{NO}_{3}-\mathrm{N}$ load when drainage water management was implemented on clay loam soil in southwestern Ontario. Lalonde et al. (1996), working with 2-year corn/soybean (Zea mays/Glycine max) rotation on a silt loam soil in Quebec, measured $\mathrm{NO}_{3}{ }^{-}$ $\mathrm{N}$ concentration reductions of $76 \%$ and $69 \%$, compared with conventional subsurface drainage, for two outlet levels in drainage water management systems.
Given the shallow water table conditions of southern Florida, even a relatively small rainfall (e.g., $10 \mathrm{~mm}$ ) can result in leaching nutrients below the root zone of crops. Traditionally, producers lower the water table under the crop if rainfall is anticipated. At most of the citrus and vegetable farms, water table is lowered by removing one or more boards in the drainage riser structure. After drainage, boards are put back in and the water table is again brought up to around $45 \mathrm{~cm}$. The drop and rise in the water table results in loss of nutrients that move from the root zone to the groundwater and then to the drainage ditch. Improving the timing and duration of drainage can reduce the nutrient discharges from the field by reducing the drainage and runoff volumes as well as reducing the movement of nutrients within the plant root zone.

As the water table is raised, the saturation zone and the capillary fringe extend toward the bed top. Fertilizers that have been placed within the bed may become solubilized with this increased wetness. The fertilizer diffuses from a dry fertilizer point source into a larger volume within and below the bed. This wetting process was the primary mechanism described by the nutrient gradient mulch system (e.g., Geraldson, 1977). While this rising water allowed soluble fertilizer to be available to plant roots, the concentration of soluble nutrients changes. As the water table recedes, the soluble fertilizer leaches out of the root zone. While it is possible for some of those soluble nutrients to move back upward into the root zone, concentrations are often dilute compared with the original soil-water solution. As a consequence, nutrients are lost from the plant uptake zone and contribute little to crop production thereafter.

Another means by which nutrients can move out of the root zone is from differences in solution density. Bonczek and McNeal (1996) conducted an experiment to study fertilizer movement in sandy soils of Florida. They found that the local density of water changes as fertilizer is solubilized. If a continuous water film exists through the soil profile, this denser fertilizer solution can move at a higher rate downward than can be explained by diffusion alone in 
the coarse-textured soils of the Florida flatwoods. Florida flatwoods includes most of the low-lying nearly level areas of the state (i.e., most of the areas at $<10 \mathrm{~m}$ elevation in Fig. 1 except numbers 27, 29, 30, and 31). For one sandy soil in the column experiment, they measured fertilizer movement at $31.2 \mathrm{~cm} \cdot \mathrm{h}^{-1}$. Because the root zone is much shallower than $0.5 \mathrm{~m}$ for most commercial horticultural crops, this so-called dropout removes nutrients beyond plant access (Bonczek and McNeal, 1996). Therefore, the common grower practice of lowering the water table for drainage purposes and bringing it back up to the 45 to $55 \mathrm{~cm}$ can result in dropping out of nutrients that leached below the root zone. Subsequently, nutrients can be moved laterally by subsurface flow and then transported off-site through the drainage ditches. To reduce these nutrient losses, water table fluctuations need to be minimized. This finding also suggests that subsurface irrigation must be closely managed to avoid fertilizer losses. These results also give a good explanation of southern Florida vegetable industry statements indicating the need for higher fertilizer rates in subsurface irrigation compared with microirrigation.

Although there are recommendations for irrigation of horticultural crops (Olson and Simonne, 2007) in Florida, no such recommendation exists for drainage. Unlike irrigation, drainage management varies considerably from farm to farm and is affected by a variety of factors including depth to the water table, relative elevation of a field within a farm, numbers and type of drainage structures and pumps, type of crop, and presence of stormwater detention/retention areas. One of the challenges in improving drainage management is the accuracy of rainfall predictions. At times, a farm is drained before the rainfall event due to time needed to drain a farm to avoid crop damage. In some instances, rainfall does not occur or is much less than anticipated. Reducing instances of unneeded drainage has the potential to reduce nutrient losses from the root zone as well as below the root zone.

The water table under flatwoods soils rises rapidly in response to rainfall or subirrigation because sandy soils are highly conductive to water flow. Using large lysimeters, Jaber et al. (2006) developed a relationship between water table change and rainfall, irrigation, and drainage for a flatwoods soil in southern Florida for plastic mulch raised bed system used for vegetable production. Jaber et al. (2006) noted that for every $1 \mathrm{~mm}$ of rainfall, the water table beneath a vegetable field can rise up to 16 times the rainfall depth. If similar relationships could be developed for major soil types where horticultural crops are grown, these relationships could be used to better predict water table rise that can then be used to make better drainage decisions. For example, consider a case of a vegetable field in southern Florida with an antecedent water table depth of $60 \mathrm{~cm}$. If the predicted rainfall for the area is $10 \mathrm{~mm}$, the relationship from Jaber et al. (2006) would predict that the water table level would rise to $44 \mathrm{~cm}$ following the rain and would likely not require drainage. Reducing the number of drainage events during a growing season can potentially reduce water use (by efficient use of rainfall) and drainage nutrient losses. The rate of water table decline is also relatively rapid (although not as fast as water table rise) if the farm drainage system is working properly. The information on water table decline can be used in decision-making related to delaying drainage and/or reducing drainage rate from the field resulting in potential reduction of nutrient losses. Appropriate water table decisions may increase the time that the field will be saturated. If the crop tolerance to different levels of flooding and the field drainage rate is known, drainage rates can be reduced to the extent that will achieve water quality and conservation benefits without adversely impacting crop production. The rate of water table recession following heavy rainfall is dependent upon the antecedent conditions, soil hydraulic properties, bed height, drainage structures, and water table gradient. Boman (1987) reported a recession time of $48 \mathrm{~h}$ or less for the water table to drop $15 \mathrm{~cm}$ for a bedded citrus grove in southern Florida. Shukla and Pandey (2008) reported water table recession of almost $50 \mathrm{~cm}$ in less than $14 \mathrm{~h}$ for a flatwoods vegetable farm in southern Florida equipped with drain tiles.

Effects of flooding on crop production need to be quantified to develop drainage management plans for specific crops. High volume rainfall events that occur in southern Florida temporarily flood the root zone of commercial crops grown in the region. The major horticultural crops grown in Florida include citrus, tomato, pepper (Capsicum annuum), watermelon, potato (Solanum tuberosum), and strawberry (Fragaria xananassa). These crops are mesophytes, requiring oxygen to the root zone due to lack of adaptation to saturated soils. Saturated soils exclude oxygen leading to anoxic conditions, and persistent refilling of the root zone with water can cause hypoxic conditions with oxygen falling to levels insufficient for aerobic respiration (Davies, 1980; Pfister-Sieber and Brandle, 1995). The flooding response of mesophytes has been extensively reviewed (Bailey-Serres and Chang, 2005; Kozlowski, 2002; Schaffer et al., 1993; Vartapetian and Jackson, 1997; Vartapetian et al., 2003). The initial response to saturated soils is a shift in energy generation from aerobic to anaerobic metabolism (Sieber and Brandle, 1991). In addition to greatly reduced energy production, anaerobiosis also causes accumulation of ethanol, acetaldehyde, and reactive oxygen species, which are toxic to plant cells. Some products of anaerobiosis, including 1-aminocyclopropane-1-carboxylic acid that promotes ethylene production (Else et al., 1995; Else and Jackson, 1998) and reactive oxygen species (Bailey-Serres and Chang, 2005), serve as secondary messengers for the aerial portion of the plant. Root anoxia causes changes in ultrastructure (Vartapetian et al., 2003), stomates to close (Bradford, 1983; Li et al., 2004; Ruiz-Sanchez et al., 1996), epinasty (Else and Jackson, 1998), reduced growth (Aloni and Rosenshtein, 1982), and reduced fruit quality and yield (Hubbell et al., 1979; Karlen et al., 1983). Prolonged flooding of mesophytes can also lead to senescence. Although the understanding of metabolic adjustment to flooding is leading to strategies for genetic modification that would enhance tolerance, the complexity of metabolism will require considerable research before genetically modified crops will be available (Allegre et al., 2004; Dolferus et al., 2003; Gharbi et al., 2007). 
Species and cultivars vary in their response to flood tolerance that will impact strategies for on-farm and regional flood control strategies. Tomato is one of the most sensitive vegetable species (Kuo and Chen, 1980; Kuo et al., 1982) with injury occurring within $24 \mathrm{~h}$ after the soil zone is flooded ( $\mathrm{Rao}$ and $\mathrm{Li}, 2003$ ). Differences in flooding response among tomato genotypes have been reported (McNamara and Mitchell, 1989; Poysa et al., 1987). Potato tubers are slightly more tolerant, losing viability after $48 \mathrm{~h}$ of anoxia (Sieber and Brandle, 1991). Watermelon plants can endure 4-d of flooding before leaf conductance and transpiration are affected (Yetisir et al., 2005). Sensitivity of citrus crops has been shown to be rootstock dependent with sour orange (Citrus aurantium) considered sensitive (Ford, 1964; Syvertsen et al., 1983), Carrizo citrange (Citrus sinensis $\times$ Poncirus trifoliata) moderately sensitive (Ford, 1964), and trifoliate orange $(P$. trifoliate $)$ moderately tolerant (Ford, 1964). Swingle citrumelo (Citrus paradisi $\times$ P. trifoliata), a rootstock that has become popular in recent years in Florida, had fewer roots below $0.5 \mathrm{ft}$ than Carrizo citrange, which may indicate greater flood sensitivity due to "root pruning" during the rainy season (Morgan et al., 2007).

In addition to the inherent species and cultivar-dependent differences, plant tolerance to anoxia is also influenced by a number of environmental factors, including duration and intensity of flooding, soil structure and chemistry, soil ecology, evaporative demand, aerial and root zone temperatures, stage of plant development, and preconditioning (Schaffer et al., 1993). Determination of flooding response for a given commercial situation will require empirical determination for specific crops and cultivars. Such information for much of the crops grown in southern Florida is lacking and will require additional research to develop strategies for water removal after a rainfall event so that the root zone of any given crop is not saturated for a period of time that would cause significant injury. This information is especially critical for crops such as bell pepper, strawberry, and watermelon, where little is known.
Once the crop-specific data on flood tolerance are available, it can be combined with rainfall, soil, and hydrologic characteristics of the farm, and type of drainage structure to develop and test farm-specific drainage management strategies with regard to production, water use, and water quality. Based on the current literature, it seems that certain crops are better suited to delayed drainage than others. For example, among the vegetable crops, watermelon seems to be a good candidate crop for which delayed drainage shows promise. Increasing residence time for drainage and runoff water in the field, ditches, and canals can reduce $\mathrm{N}$ and $\mathrm{P}$ loadings. Shukla et al. (2006) showed that increased residence time of drainage from a southern Florida cow-calf ranch resulted in reducing soluble $\mathrm{P}$ loadings by as much as $50 \%$. Similar results can be expected for horticultural crops in southern Florida due to similar soil, hydrologic, and weather conditions.

Overall, limited research has been conducted in Florida to develop soil- and crop-specific drainage guidelines and evaluate the effects of drainage strategies with regard to water conservation, $\mathrm{N}$ and $\mathrm{P}$ loadings, and crop production. Given the demonstrated benefits of drainage management strategies in other soil-hydrologic regions of the United States., these strategies have the potential to reduce the mass of nutrients that can leach or have already leached below the crop root zone. From the standpoint of adverse impacts on water resources, more emphasis is needed on controlling $\mathrm{P}$ discharges because $\mathrm{P}$ is the limiting nutrient for the major water bodies in southern Florida such as the sensitive Lake Okeechobee and Everglades ecosystem. The published data on the effectiveness of drainage management strategies on $\mathrm{P}$ discharge is limited for Florida and elsewhere in the nation. Although developing and implementing crop-specific drainage management will help reduce the drainage volume from the fields, it cannot completely eliminate the drainage discharges especially from large rainfall (e.g., a $10 \mathrm{~cm}$ rainfall) events. For such events, temporarily detaining the runoff and drainage from fields at an on-farm downstream location may help further reduce the water and nutrient discharges.

\section{Water detention/retention and water recycling}

Detention is commonly used to describe the temporary storage of water on the land such as in ponds before final discharge to downstream water bodies (e.g., river). Retention, on the other hand, refers to the storage of water for an extended period of time. The most common water detention/retention practice for horticultural crops in Florida is stormwater detention areas. Often, terms such as impoundments, reservoirs, and ponds have been used to describe detention structures.

STORMWATER IMPOUNDMENTS. In most modern horticultural crop farms in southern Florida and parts of central and northern Florida, stormwater impoundments are present to reduce downstream flooding. By law, a southern Florida landowner cannot alter historic hydrologic water discharges from his/her property (South Florida Water Management District, 2007). Hence, producers in southern Florida, including citrus, vegetables, and nursery producers, are required to build and maintain stormwater impoundments. Historically, these structures have been designed for the sole purpose of controlling downstream flooding.

Typical stormwater impoundments are aboveground structures and consist of water detention areas surrounded by dikes (Fig. 2) (Jaber and Shukla, 2004). Impoundments are designed to store the first 1 inch of runoff from the drainage area to meet the off-site discharge limit that is equal to historic discharges (if available), or discharges from a 3-d, 25year storm event. All impoundments are surrounded by a "borrow" ditch, which serves to collect runoff and drainage from the farm. Using a "throw-out" pump, water from the inflow borrow ditch is pumped into the impoundment. After water in the impoundment exceeds the outflow weir elevation, water is discharged into downstream water bodies such as a river or lake (Fig. 2).

In addition to flood control, impoundments are also effective in retaining nutrients and reducing nutrient discharges from the farms. Among different BMPs for reducing nutrient losses from horticultural crops, impoundments are assumed to be the most effective BMP. Some 
impoundments contain functioning wetlands. Impoundments reduce nutrient loading through physical, biological, and chemical processes. Excess $\mathrm{N}$ and $\mathrm{P}$ loadings are of concern in Florida. Drainage water that is pumped into the impoundment contains particulate and dissolved forms of $\mathrm{N}$ and P. Wet detention/retention systems vary widely in their ability to remove pollutant from water with high removal rates for selected nondissolved contaminants. Some of the most important removal processes are purely physical such as sedimentation via reduced water velocity and filtration by hydrophytic vegetation (Boman et al., 2008). These processes can result in high removal rates for suspended solids, particulate organic matter [particulate biochemical oxygen demand (BOD)], and sediment-bound nutrients. Similarly, some pathogens are also effectively removed in wet detention/retention systems via sedimentation and filtration, natural dieoff, and by ultraviolet degradation.

Dissolved constituents such as soluble organic matter, $\mathrm{N}$, and $\mathrm{P}$ tend to have lower removal rates than particulate constituents (U.S. Environmental Protection Agency, 1999). Soluble organic matter (such as dissolved organic $\mathrm{N}$ and $\mathrm{P}$ ) is largely degraded by bacteria in the water column, plant-attached algal and bacterial associations, and microbes at the sediment surface. $\mathrm{N}$ is removed largely through microbial action (e.g., denitrification), plant uptake, and volatilization. Denitrification involves converting nitrate-nitrite ( $\mathrm{NOx}$ ) to gaseous forms of $\mathrm{N}$, thereby reducing dissolved $\mathrm{N}$ concentrations. Microbial degradation processes are relatively slow, particularly from anaerobiosis that require longer residence times, a factor that contributes to the more variable performance of wet detention/retention systems for these dissolved constituents. P is primarily removed through soil sorption processes that are slow and vary based on soil properties. These processes are likely similar to those in warm, shallow water bodies, such as lakes. Although most impoundments reduce the nutrient discharges, there are several avenues that can enhance their nutrient treatment efficiencies. These enhancements include: 1) harvesting and reusing the water and plant material from the impoundment; 2) increasing the hydraulic efficiency of these impoundments; 3) modifying the vegetation within the impoundment; and 4) amending the soil within the impoundment.

Shukla and Jaber (2006) found that an impoundment has the potential to act as a stormwater harvesting unit and become sources of alternative water supply during the wet (JuneSeptember) and dry (October-May) seasons. Jaber and Shukla (2004) evaluated the feasibility of using agricultural impoundments as sources of alternative water supply within the Caloosahatchee watershed in southern Florida. In present conditions, the impoundment water level went below the useable levels within 1 month after the wet season ended (Shukla and Jaber, 2002). Subsurface losses were the main avenue for water lost from impoundments. Using a hydraulic/hydrologic simulation model and hydrologic data from a southern Florida impoundment, Jaber and Shukla (2004) found that some managerial and structural changes in the impoundment could extend the useable storage from the impoundment. These changes include recapture of seepage losses and pumping back into the impoundment structure (recirculation) (Table 1) using the existing pump(s) and lining part or all of the impoundment area. Using impoundment storage for irrigation can potentially reduce the nutrient loads by reducing the nutrient concentration as well as volume of water leaving the impoundment. Use of impoundment storage for irrigation can reduce the net volume of water leaving the impoundment and therefore reduce nutrient loading. Increased nutrient retention within the impoundment as well as cropped areas is achieved by increasing water residence time, promoting crop and other plant uptake of nutrients, and nutrient retention through physical (e.g., sorption) and biological (e.g., denitrification) processes. Additionally, accounting of $\mathrm{N}$ and $\mathrm{P}$ contribution from recycled

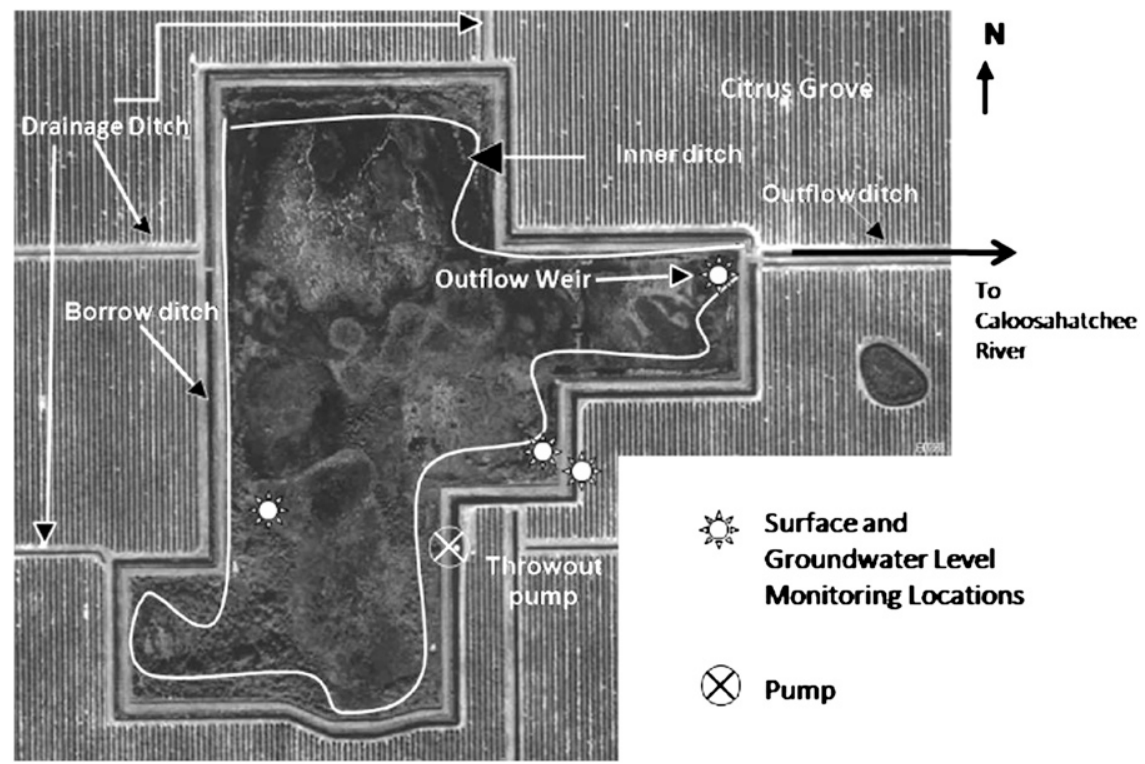

Fig. 2. Aerial photo of an impoundment in a citrus grove (from Jaber and Shukla, 2004).

Table 1. Weeks of irrigation supply for structural and managerial changes for an impoundment in southern Florida (Jaber and Shukla, 2004).

\begin{tabular}{llc}
\hline Modifications & \multicolumn{1}{c}{ Description $^{\mathrm{z}}$} & $\begin{array}{c}\text { Irrigation } \\
\text { (weeks) }\end{array}$ \\
\hline 1 & Lining entire reservoir with $0.15-\mathrm{m}$ clay liner & 13 \\
2 & Lining inside ditch and embankments with $0.15-\mathrm{m}$ liner & 3 \\
3 & Lining inside ditch and embankments with $0.30-\mathrm{m}$ liner & 4 \\
4 & Recirculation & 4 \\
\hline
\end{tabular}


water from impoundment could reduce the amount of fertilizer $\mathrm{N}$ and $\mathrm{P}$ inputs to the crop, which can potentially reduce the $\mathrm{N}$ and $\mathrm{P}$ loadings from the farm. Modifying impoundments to extend their useable storage for irrigation may require substantial investment in irrigation infrastructure by growers. Given the societal benefits resulting from the use of impoundment storage, innovative approaches are needed to facilitate these modifications.

The use of distributed impoundments as an alternative source of water supply at the watershed scale can result in economic and environmental benefits. Given the distributed nature of impoundments, they can act as distributed water supply reservoirs. Compared with other water supply storage structures such as reservoirs, impoundments do not require additional land area. Impoundment water used for irrigation can reduce the amount of water pumped by agriculture from traditional surface and groundwater sources, increasing the amount of water available to other water consumers (Shukla et al., 2008). If appropriate policy mechanisms exist, farmers can "sell" their reductions in water use to urban water supply utilities, which are demanding additional water for growing populations. Currently, landowners do not own the groundwater they use for irrigation and are not allowed to sell it. If landowners are allowed to trade water credits with urban communities, it could potentially generate an additional source of income for agricultural landowners (Shukla, 2006; Shukla et al., 2008). In addition to economic benefits from the water supply aspects, use of these impoundments to treat the water from public canals (Bohlen et al., 2008) or other neighboring land uses (agricultural or urban) to meet water quality goals can also generate additional income for the grower.

The use of impoundment storage for irrigation can reduce farmscale water discharges to the rivers and lakes and help meet maximum flow levels to the estuarine systems. Modification of impoundments to increase dry period storage can also have positive impacts on wildlife. A 5year study by Main and Allen (2007) to evaluate wildlife use in a similar agricultural impoundment located in southwestern Florida showed wetland habitats within impoundments attracted a variety of avian species. Economic benefits obtained from providing environmental services from these impoundments could not only pay for the impoundment modifications, but could also provide a net profit to the grower.

Several hydraulic design modifications can be made to enhance hydraulic and nutrient treatment efficiency of impoundments ( $S$. Shukla and F.H. Jaber, unpublished data). In some impoundments, inflow and outflow locations are close to each other, which reduces the residence time in the impoundment. Increased residence time has been shown to result in $\mathrm{N}$ and $\mathrm{P}$ retention in a cattle ranch drainage ditch in southern Florida (Shukla and Collins, 2005). Similar results were also reported by Edwards et al. (1999), who reported on a simulated agricultural runoff event where water amended with sediment, $\mathrm{N}$, and $\mathrm{P}$, was passed through an experimental sedimentation basin. An average of $94 \%$ of the sediment, $76 \%$ of the $\mathrm{N}$, and $52 \%$ of the $\mathrm{P}$ added to the inflow were retained by the basin in Pennsylvania. The 3 -d retention time treatment retained significantly more sediment than the 1 -d treatment. The majority of the sediment, $\mathrm{N}$, and $\mathrm{P}$ were released within the first $12 \mathrm{~h}$ during the 3 - $\mathrm{d}$ runs and the first $4 \mathrm{~h}$ during the $\mathrm{l}-\mathrm{d}$ runs.

Using soil amendments inside the impoundment can increase the nutrient retention within the impoundment. Impoundments tend to "leak" through the berm to the outside perimeter ditch and through the bottom (Jaber and Shukla, 2004). This fact suggests that soluble forms of $\mathrm{P}$, which are difficult to remove from the water column, are also exposed to reactions with organic matter and soil due to water losses from the impoundment. This leakage could also result in reactions created by providing reactive materials, such as finely ground limestone to react with soluble reactive $\mathrm{P}$ and ligands to react with organic forms of $\mathrm{P}$. Successful use of these materials with impoundments has not been tested (Hanlon et al., 2007). P is also removed through plant assimilation and subsequent burial in organic litter. Consequently, P removal rates are variable and typically lower than for
N. Impoundments that incorporate wetland plants can be expected to achieve or exceed pollutant removal rates estimated for wet detention alone.

In summary, the research needs for understanding and enhancing the environmental benefits including the nutrient treatment efficiency of the impoundments are: 1) quantification of treatment efficiencies of stormwater impoundments; 2) effects of hydraulic designs on water and nutrient retention; 3 ) effects of using the impoundment water for irrigation (discussed in the next section) on water use and quality; 4) effects of harvesting the organic matter from the impoundment and using it as amendment in the cropped areas or as potential feedstock for biofuel, on nutrient retention and water quality; 5) effects of using soil amendments such as lime to increase the $\mathrm{P}$ retention; 6) effects of using these impoundments as water harvesting units at the watershed-scale on water supply, water quality, and farm income.

TAIlWATER RECOVERY AND USE. Recycling of runoff and drainage originating from Florida's agricultural areas has the potential to provide water conservation as well as water quality benefits. The runoff and drainage in a farm can be stored at the tail end of the farm and used for irrigation. In southern Florida, most of the stormwater impoundments are located at lower elevations within the farm. The use of these impoundments to store drainage/runoff and use this storage for irrigation is similar to a tailwater recovery system. Farms that do not have such storage areas can construct an impoundment. To use the impoundment as part of a tailwater recovery and reuse system, additional irrigation infrastructure would be needed. These include pumps, water treatment systems, and irrigation conveyance systems to deliver the tailwater back to the crop. The cost for the additional infrastructure would vary depending on the crop and the type of irrigation used at the farm. For example, if seepage irrigation is used, the additional cost for using the impoundment storage would be less than at farms where microirrigation is used. For seepage irrigation, the impoundment storage can simply be pumped to the irrigation ditches that are used to maintain 
the water table in the production fields.

Water treatment systems may be needed to remove plant pathogens in recycled water used irrigation because this source can potentially reintroduce economically important disease pathogens. Several plant pathogens, including bacteria (Schuster, 1959; Thompson, 1965), fungi and oomycetes (Dukes et al., 1997; Easton et al., 1969; Gill, 1970; MacDonald et al., 1994), and nematodes (Faulkner and Bolander, 1970) have been found in surface irrigation water. These water sources may contain more than one potential pathogen (Roberts et al., 2005). Irrigation water contaminated with plant pathogens was implicated in initiating disease outbreaks on certain field crops (McIntosh, 1966; Whiteside and Oswalt 1973).

The presence of pathogens in runoff and drainage water has also been investigated in Florida. An outbreak of Phytophthora citrophthora in citrus in central Florida was related to overhead sprinklers and the irrigation pond source was shown to contain the pathogen (Whiteside and Oswalt, 1973). Phytophthora capsici and other plant pathogenic oomycetes were recovered in runoff water from ponds and canals in southern Florida (Roberts et al., 2005). Several species of Pythium and Phytophthora species caused disease on pepper and tomato in plant bioassays. Thus, in Florida, the potential exists for reintroduction and dissemination of plant pathogens by the use of recycled water for irrigation, therefore, decontamination of irrigation water may be warranted to avoid plant disease epidemics initiating from inoculums in recycled water.

Transmission of human pathogens via irrigation water is also a concern as highlighted recently in the popular press with two incidents involving spinach (Spinacia oleracea) and muskmelon (Cucumis melo). Fresh and precut fruit and vegetables may become contaminated if exposed to irrigation sources containing human pathogens. By regulation, contact of plants with effluent irrigation water is not allowed in Florida for produce that is not peeled, cooked, or thermally processed for the consumer. This requirement eliminates the use of sprinkler or overhead irrigation with recycled water. However, seep or drip irrigation is not a problem because neither of these involves direct contact with the plants. However, treatment of irrigation water to improve quality and to reduce the risk of plant and human disease transmission may be needed before using recycled water.

Various physical and cultural treatment regimes may be needed to improve water quality and reduce plant pathogen transmission in commercial operations. Some options include sand filtration, chlorine, and ultraviolet light to remove microorganisms from contaminated water. Sand filtration systems (SFS) use physical and biological activity to decontaminate water. In an SFS system, the filter bed contains a medium with high surface area into which suppressive microorganisms such as species of bacteria in the genus Pseudomonas and the fungus Trichoderma, with demonstrated ability as biological control agents, is introduced and allowed to colonize the surface thus reducing microorganism in the water source. Chlorine $(\mathrm{Cl})$, widely used in some commercial vegetable and citrus operations to clean and maintain irrigation systems, also improves water quality by killing microorganisms, in particular bacteria, and altering some chemicals that affect the taste, odor, and color of water. Ultraviolet light exposure is also used for water disinfection causes molecular rearrangement of DNA of microorganisms, preventing organisms from reproducing (Mebalds et al., 1996). The efficiency of ultraviolet depends upon contact time and light intensity.

In southern Florida, detection of plant pathogens in tailwater suggests that if this water source is used to irrigate a field growing susceptible plants, there is potential for pathogen dissemination and disease to occur. However, the interaction of many factors (e.g., plant susceptibility and age, pathogen concentration, cultural practices, and environmental conditions) influence whether a disease occurs or not. It is important to consider these factors when making decisions about implementing disease management practices with recycled water, for example, not using recycled water on transplants that are typically quite susceptible to the damping-off pathogen Pythium sp. that is frequently present in tailwater
One of the effects of using tailwater that has received attention in the arid west of the United States is high salinity and its adverse effects on crop yield (Corwin and Bradford, 2008). In Florida, salinity problems have been mainly due to salt water intrusion in the coastal areas and salinity problems associated with tailwater use have not been reported. Other issues emerging from the use of tailwater may include clogging of microirrigation system by biological growth. However, use of the abovementioned disinfectants (e.g., $\mathrm{Cl}$ ) to remove plant pathogens is likely to reduce or eliminate such effects.

There is a lack of published evidence on the long-term sustainability of recycling degraded water such as tailwater (O'Connor et al., 2008). Currently, limited or no literature exists that has quantified the effects of recycling tailwater on $\mathrm{N}$ and $\mathrm{P}$ discharges in Florida or elsewhere in the world. Although tailwater recycling has been promoted, several questions regarding its efficacy need to be answered to facilitate wide-scale adoption. Research needs for on-farm tailwater recycling are: effects on farmscale $\mathrm{N}$ and $\mathrm{P}$ loadings, surface and groundwater withdrawals for irrigation, and farm income; effects on viability of plant pathogens and crop production; and nutrient value of tailwater to partly offset the $\mathrm{N}$ and $\mathrm{P}$ fertilizer needs of the crop.

\section{Summer flooding}

A large fraction of vegetable fields are kept fallow during the June-August period. High water table conditions combined with the fact that almost $70 \%$ of rainfall in southern Florida occurs from June to October can result in occasional flooding of vegetable production fields. Flooding is especially likely after a tropical storm or hurricane. If fields are allowed to be flooded for a prolonged period without drainage, it may not only reduce nutrient loadings from the farm, but also decrease the potential for plant pathogen survival and root anoxia (Maas, 1987). Periodic flooding to alternate anaerobic and aerobic conditions decreases nematode populations (Dunn and Noling, 1995). In Florida organic soils, as little as 2 weeks of flooding followed by 2 weeks of drainage, drying, and disking was as effective to reduce 
nematodes as continuous flooding for 9 months (Stover, 1979). Fields in southern Florida are particularly amenable to this method because of the naturally high water table.

An additional benefit of maintaining a high water table during fallow period is reduction of $\mathrm{NO}_{3}-\mathrm{N}$ content of the soil and the shallow groundwater due to denitrification. Studies on a loam soil showed a 4fold increase in denitrification from that soil when the water table was at a depth of $15 \mathrm{~cm}$ compared with $45 \mathrm{~cm}$ (Kliewer and Gilliam, 1995). Although potentially an attractive option, the effect of this practice on nutrient loading has not been quantified for southern Florida conditions.

\section{Managing drainage and runoff water quality}

A wide variety of managerial and structural practices are available that can reduce the mass of nutrient leached below the crop root zone before nutrients leave the farm through physical, biological, and chemical processes [Florida Department of Agriculture and Consumer Services (FDACS), 2005, 2008). Examples of structural practices include using riser board in place of screw gate structures to reduce erosion and sediment-bound nutrient losses. With riser-board structures, water is forced to flow over the top of the boards (FDACS, 2005). This flow path creates a low current area toward the bottom of the structure, which facilitates the deposition of sediments and accompanying nutrients or pesticides, essentially removing them from the discharges. Conversely, screwgates do not create this dead-current zone. Because screw-gates open from the bottom, sediments and accompanying load are swept out along with the discharge water.

Settling basins or settling ponds are another simple way to remove sediments out of runoff water. Settling basins simply slow down the water and reduce turbulence, allowing sediments to fall to the basin bottom before the water returns to the receiving water body. Water discharging from settling basins will be lower in suspended solids concentrations and concentrations of Total $\mathrm{N}$, Total $\mathrm{P}$, and $\mathrm{BOD}$ than water entering them. An Oregon study (Oregon
Department of Agriculture, 2003) showed a $60 \%$ reduction in turbidity and suspended solids for water passing though a sediment basin at field edge.

Managerial practices include maintenance of VFS along the drainage and runoff pathways to retain nutrients. Some selected practices are discussed below.

\section{Vegetated filter strips}

VFS remove sediment and other pollutants such as nutrients, pesticides, organic material, and trace metals (Table 2) from runoff and drainage by filtration, deposition, infiltration, absorption, adsorption, decomposition, and volatilization, thereby reducing the amount of pollution entering surface waters (USDA, 1988). These strips have higher efficiency for removal of particulate pollutants than for removal of soluble pollutants (Schueler, 1987). Filter strips should not be relied on as the sole or primary means of preventing nutrient movement from cropland (Lanier, 1990).

VFS are appropriate for use in areas adjacent to surface water systems that may receive runoff containing sediment, suspended solids, and/ or nutrient runoff. VFS are designed to be used in conditions where runoff passes over the vegetation in a uniform sheet flow. If runoff is allowed to concentrate or channelize, the VFS is easily inundated and will not perform as it was designed to function. Therefore, VFS systems are most applicable to areas in central and northern Florida that have considerably deeper water tables than in southern Florida.

VFS need the following elements to work properly: 1) a device such as a level spreader that ensures that runoff reaches the VFS as a sheet flow (berms can be used for this purpose if they are placed at a perpendicular angle to the VFS area to prevent concentrated flows); 2 ) a dense vegetative cover of erosion-resistant plant species; 3) a slope of no more than $5 \%$; and 4 ) a length at least as long as the adjacent contributing area (Schueler, 1987). If these requirements are met, VFS have been shown to remove a high degree of particulate pollutants, with as much as $92 \%$ of sediment (Blanco-Canqui et al., 2004) and more than $70 \%$ of TKN and total $\mathrm{P}$ removed ( $\mathrm{Lim}$ et al., 1998).
Several studies show that VFS improve water quality. The VFS are most effective at sediment removal, with rates generally greater than $70 \%$ (Table 2). The published results on the effectiveness of VFS in nutrient removal are more variable, but $\mathrm{N}$ and $\mathrm{P}$ removal rates are typically greater than $50 \%$ (Table 2 ). With proper planning and maintenance, VFS can help improve water quality when coupled with 1 ) farming practices that reduce nutrient inputs or minimize soil erosion or 2) detention ponds to collect runoff as it leaves a VFS.

Southern Florida has considerably different soil, topography, and hydrology than other physiographic regions of the United States. The runoff produced by high-intensity rain storms may reduce the effectiveness of VFS and favor grassed waterways. The effectiveness of VFS in southern Florida may be considerably different from the published literature. Therefore, Florida-specific studies are needed to quantify the effectiveness of this BMP before its wide-scale adoption.

\section{Cleaning and dredging \\ of drainage ditches}

Almost all agricultural operations in southern Florida contain an extensive network of drainage ditches to drain and at times irrigate the horticultural cropland. Depending on the specific farm hydraulic system and its management, there is generally a layer of light sediment floccule material accumulated at the interface between the sediment bed and water column in the ditch that has high $\mathrm{P}$ content. Organic floccule material is easily suspended and transported during drainage events. Daroub et al. (2002) reported that particulate $\mathrm{P}$ accounted for up to $50 \%$ of the P loading from the Everglades Agricultural Area (EAA). The source of most of this P (approx 60\%) was found to be biological matter (e.g., floating aquatic weeds, submerged aquatic growth) growing in the drainage and irrigation canals. Sediment surveys of selected farm drainage canals in the EAA showed that sediments tend to accumulate in main drainage canals upstream of drainage structures. The sediment survey reported that there was sufficient $P$ in the accumulated sediments to supply particulate $\mathrm{P}$ for several years if the 
Table 2. Selected references reporting effectiveness of vegetative filter strips (VFS) for pollutant removal (adapted from U.S. Environmental Protection Agency, 2008).

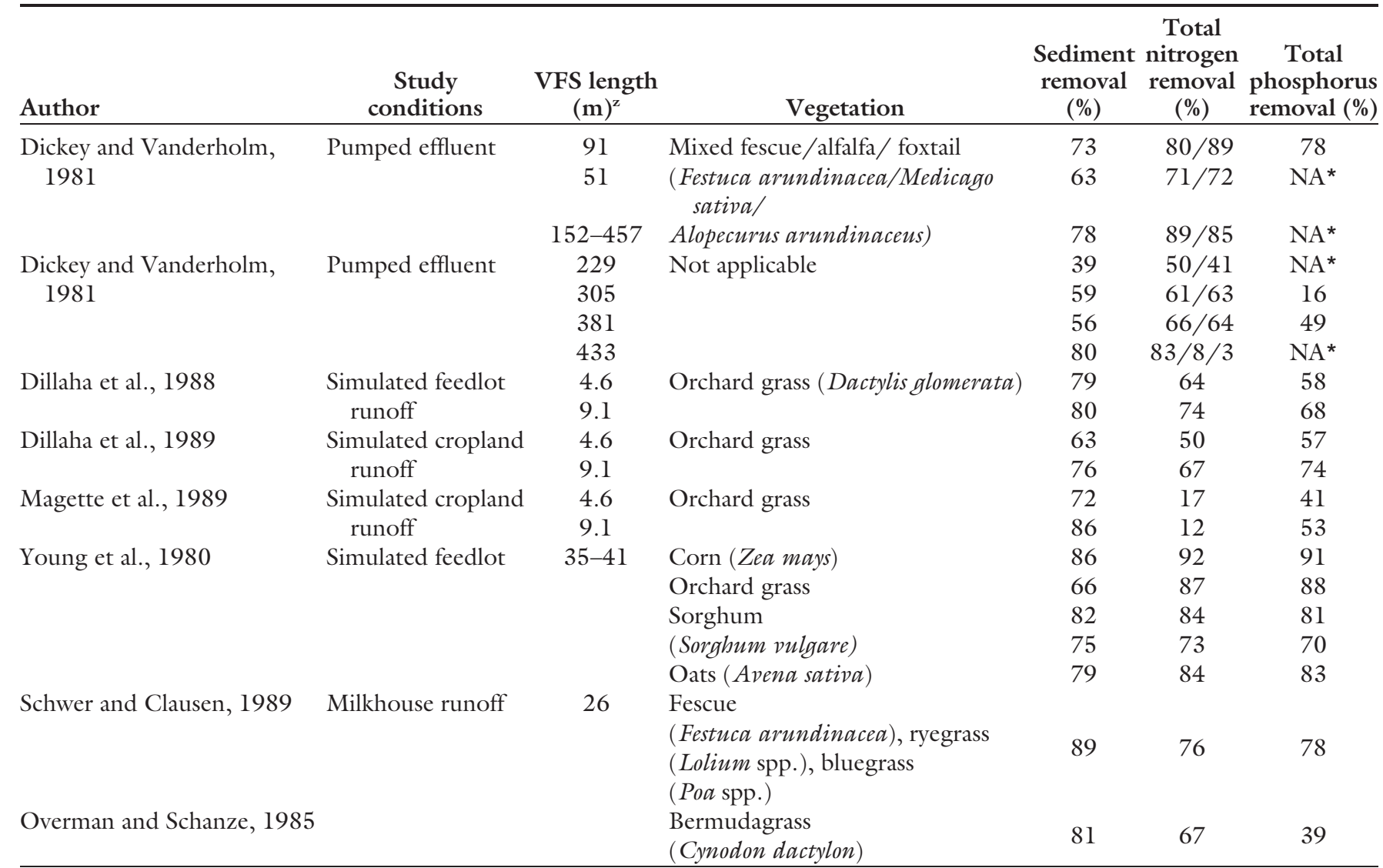

${ }^{\mathrm{z}} 1 \mathrm{~m}=3.2808 \mathrm{ft}$.

sediment was not removed (Diaz et al., 2008).

A canal cleaning program reduces sediment material that has accumulated in the canal systems. Canal cleaning should be conducted during quiescent conditions. Biological growth in main farm canals is the primary contributor to particulate $\mathrm{P}$; thus, it is important to regularly clean the canal sections directly upstream of main drainage structures. In addition, drainage pumping during or immediately after canal cleaning is to be avoided so as not to release drainage waters of high sediment concentration. Spoil material should be removed and deposited on a self-contained, upland spoil site that will prevent the movement of the water and excavated spoil material into wetlands or other surface waters. Erosion and sedimentation control devices (e.g., turbidity screens) should be used to prevent bank erosion and scouring and to prevent turbidity from discharging into adjacent waters during maintenance dredging. Potential uses of the biological growth could include reuse as compost or for biofuel production; however, such uses and the potential benefits and challenges have not been investigated.

Removal of accumulated sediment generally increases the canal cross-sectional area and reduces water velocities, thus reducing the potential for bank scouring. Diaz et al. (2008) describe the following practices to reduce particulate $\mathrm{P}$ and sediment discharges in farm drainage in the EAA: ditch and canal bank berms; main canal sediment sumps and traps; sediment sumps in field ditches; regular canal and field ditch cleaning; slowed drainage near exit pump stations; installation of raised culverts; and vegetated ditch banks for stabilization. Although studies have been conducted in southern Florida to characterize the resident $\mathrm{P}$ mass in the drainage network, limited published data are available on the actual effectiveness of ditch cleaning on $\mathrm{N}$ and $\mathrm{P}$ loadings. Such information is needed, especially for the long-term, to quan- tify the effectiveness of ditch cleaning in reducing the $\mathrm{N}$ and $\mathrm{P}$ losses from fruit and vegetable farms.

\section{Summary and research needs}

Florida's unique hydrology and climate result in high nutrient leaching losses from farms, especially after high rainfall events. A variety of approaches ranging from drainage management to on-farm recycling of drainage and runoff have the potential to reduce the nutrient loadings from farm. Strategies for reducing unavoidable nutrient losses from the shallow water table environments of Florida need a systems approach that includes practices targeting water and nutrient retention from the production field to the drainage ditches and finally to the farm outlet. Drainage management includes controlling drainage to reduce the drainage volume for specific crops. For large rainfall events that require drainage, stormwater impoundments can be used to reduce water and nutrient discharges. To further enhance the 
effectiveness of stormwater impoundments, the water stored in the impoundment could be used as a source of irrigation, moving nutrient loadings from the drainage water to the irrigation source and enhancing both nutrient and water recycling. Although the recycling of stormwater for irrigation is an attractive option, careful management is needed to prevent the spread of economically important pathogens through the recycled water. Practices such as placing VFS or grass waterways that target the nutrient reduction at a variety of locations within a farm can reduce the entry of nutrients to the drainage ditches. Maintenance cleaning of ditches can help reduce the amount of $\mathrm{N}$ and $\mathrm{P}$ loadings by reducing the amount of nutrients that have already moved into the ditch and been taken up by the aquatic plants. Although several strategies exist for reducing nutrient losses from horticultural crops, limited data exists in Florida on their effectiveness with regards to nutrient losses and crop production. A summary of future research needs to address the reduction of nutrient losses from Florida's horticultural crops is given below:

- Develop and evaluate tools for managing drainage under high water table conditions. The use of such tools can reduce the drainage volume, nutrient loading, and water use. Examples include: a) prediction of water table response to a rainfall and drainage event for different soil types and using these relationships to make drainage decisions; b) soil moisturebased drainage management; and c) delaying drainage by reducing the drainage rate and volumes. Quantify the effects of using these practices on water use, quality, plant disease, and crop production.

- Determine the flooding tolerance and survival of plant pathogens for some of the most commonly grown commercial citrus rootstocks and vegetable cultivars under different drainage conditions. Evaluate new cultivars that may have enhanced flooding tolerance. This evaluation should be in conjunction with the preceding research need to design crop-specific drainage management practices that may reduce the rate and volume of drainage, conserve water, and reduce nutrient loadings without adversely impacting crop yield.
- Develop tools to analyze hydrologic performance of drainage infrastructure to: a) determine the need for system improvements (water control structures, ditch capacity, pumps, etc.) to provide adequate drainage to protect crops while retaining as much water on site as possible, and b) develop operating criteria to effectively manage the system under various rainfall scenarios.

- Quantify water and nutrient dynamics in stormwater impoundments. Identification and evaluation of strategies to enhance the nutrient treatment efficiency of impoundments. These include modifications to increase the hydraulic efficiency and increased retention by soil and plants.

- Develop and evaluate tailwater reuse strategies with regards to water and nutrient discharge, production, and farm income. Tailwater reuse includes the construction of new storage infrastructure as well as modifications to the existing stormwater impoundments to facilitate water reuse.

- Evaluate the effectiveness of ditch management (cleaning and VFS) practices with regards to reducing $\mathrm{N}$ and $\mathrm{P}$ discharges.

- Evaluate the effects of summer flooding on water and nutrient discharges, plant disease, and crop production.

- Evaluate the feasibility of using agricultural areas (e.g., stormwater impoundments) for water harvesting and use this water for on-farm irrigation and "banking and trading" with the urban sector for economic benefits to the landowner. Effects of these strategies on watershed water supply, surface water flows, groundwater levels, water quality, and wildlife.

\section{Literature cited}

Allegre, A., J. Silvestre, P. Morard, J. Kallerhoff, and E. Pinelli. 2004. Nitrate reductase regulation in tomato roots by exogenous nitrate: A possible role in tolerance to long-term root anoxia. J. Expt. Bot. 55:2625-2634.

Aloni, B. and G. Rosenshtein. 1982. Effect of flooding on tomato cultivars: The relationship between proline accumulation and other morphological and physiological changes. Physiol. Plant. 56: 513-517.

Bailey-Serres, J. and R. Chang. 2005. Sensing and signalling in response to oxygen deprivation in plants and other organisms. Ann. Bot. (Lond.) 96:507518.

Berndt, M.P., E.T. Oaksford, and G. Mahon. 1998. Groundwater, p. 38-63. In: E.A. Fernald and E.D. Purdum (eds.). Water resources atlas of Florida. Inst. Sci. Public Affairs. Florida State Univ., Tallahassee.

Black, R.J. 2003. Florida climate data. Univ. Florida, Inst. Food Agr. Sci., Coop. Ext. Publ. EES5. 14 Nov. 2008. <http:// edis.ifas.ufl.edu/EH105>.

Blanco-Canqui, H., C.H. Gantzer, S.H. Anderson, E.E. Alberts, and A.L. Thompson. 2004. Grass barriers and vegetative filter strips effectiveness in reducing runoff, sediment, N, and phosphorus losses. Soil Sci. Soc. Amer. J. 68:1670-1678.

Bohlen, P.J., S. Lynch, L. Shabman, M. Clark, S. Shukla, and H. Swain. 2008. Paying for environmental services from agricultural lands: An example from the northern everglades. Front. Ecol. Environ 7(10):46-55.

Boman, B.J. 1987. Effects of soil series on shallow water table fluctuations in bedded citrus. Proc. Florida State Hort. Soc. 100:137-141.

Boman, B.J. and P.C. Wilson. 2003. Water table management as a BMP for reducing discharges from Indian River citrus groves: Modeling study. Indian River Res.0 Educ. Ctr. (IRREC) Res. Rpt. FTP2003-1. Univ. Florida. IRREC, Fort Pierce.

Boman, B.J., P.C. Wilson, M. Jennings, and S. Shukla. 2008. Detention/retention for citrus stormwater management. Univ. Florida, Inst. Food Agr. Sci. Ext. Publ. AE 1405. 2 Apr. 2008. <http:// edis.ifas.ufl.edu/AE216>.

Bonczek, J.L. and B.L. McNeal. 1996. Specific-gravity effects on fertilizer leaching from surface sources to shallow water tables. Soil Sci. Soc. Amer. J. 60:978-985.

Bradford, K.J. 1983. Effects of soil flooding on leaf gas exchange of tomato plants. J. Amer. Soc. Hort. Sci. 73:475-479.

Burchell, M.R., II, R.W. Skaggs, G.M. Chescheir, J.W. Gilliam, and L.A. Arnold. 2005. Shallow subsurface drains to reduce nitrate losses from drained agricultural lands. Trans. Amer. Soc. Agr. Eng. 48: 1079-1089.

Calvert, D.V., R.C. Koo, and H.W. Ford. 1967. Flood irrigation studies with citrus. Proc. Florida State Hort. Soc. 80:79-85.

Cooke, R.A., G.R. Sands, and L.C. Brown. 2005. Drainage water management: A practice for reducing nitrate loads from subsurface drainage systems. Proc. Gulf 
Hypoxia and Local Water Quality Concerns Wkshp. Amer. Soc. Agr. Biol. Eng. 26-28(Sept):19-28

Corwin, D.L. and S.A. Bradford. 2008. Environmental impacts and sustainability of degraded water reuse. J. Environ. Qual. 37:S-1-S-7.

Daroub, S.H., J.D. Stuck, T.A. Lang, and O.A. Diaz. 2002. Particulate phosphorus in the everglades agricultural area: I Introduction and sources. Univ. Florida, Inst. Food Agr. Sci., Coop. Ext. Publ. SL197. 11 Nov. 2008. <http://edis.ifas. ufl.edu/SS410/>.

Davies, D.D. 1980. Anaerobic metabolism and the production of organic acids, p. 581-611. In: D.D. Davies (ed.). The biochemistry of plants Vol. 2. Academic Press, New York.

Diaz, O.A., T.A. Lang, S.H. Daroub, and M. Chen. 2008. Best management practices in the everglades agricultural area: Controlling particulate phosphorus and canal sediments. Univ. Florida, Inst. Food Agr. Sci., Coop. Ext. Publ. SL228. 11 Nov. 2008. <http://edis.ifas.ufl.edu/ SS448/>.

Dickey, E.C. and D.H. Vanderholm. 1981. Vegetative filter treatment of livestock feedlot runoff. J. Environ. Qual. 10:279-284.

Dillaha, T.A., J.H. Sherrard, D. Lee, S. Mostaghimi, and V.O. Shanholtz. 1988. Evaluation of vegetative filter strips as a best management practice for feed lots. J. Water Pollut. Control Fed. 60:1231-1238.

Dillaha, T.A., R.B. Reneau, S. Mostaghimi, and D. Lee. 1989. Vegetative filter strips for agricultural nonpoint source pollution control. Trans. Amer. Soc. Agr. Eng. 32:513519.

Dolferus, R., E.J. Klok, C. Delessert, S. Wilson, K.P. Ismond, A.G. Good, W.J. Peacock, and E.S. Dennis. 2003. Enhancing the anaerobic response. Ann. Bot. (Lond.) 91:111-117.

Doty, C.W., J.E. Parsons, A.W. Badr, A. Nassehzadeh-Tabrizi, and R.W. Skaggs. 1985. Water table control for water resource projects on sandy soils. J. Soil Water Conserv. 40:360-364.

Drury, C.F., C.S. Tan, J.D. Gaynor, T.O. Oloya, and T.W. Welacky. 1996. Influence of controlled drainage-subirrigation on surface and tile drainage nitrate loss. J. Environ. Qual. 25:317-324.

Dukes, P.D., S.F. Jenkins, Jr., and S.S. Thompson, Jr. 1997. Detection and some observations of Phytophthora parasitica var nicotianae in ponds used for irrigation of tobacco. Tobacco Sci. 2:97-100.
Dunn, R.A. and J.W. Noling. 1995. Florida nematode control guide. Florida Coop. Ext. Serv., Inst. Food Agr. Sci., Univ. Florida, Gainesville.

Easton, D.D., M.E. Nagle, and D.L. Bailey. 1969. A method of estimating Verticillium albo-atrum propagules in field soil and irrigation waste water. Phytopathology 59:1171-1172.

Edwards, C.L., R.D. Shannon, and A.R. Jarrett. 1999. Sedimentation basin retention efficiencies for sediment, $\mathrm{N}$ and $\mathrm{P}$ from simulated agricultural runoff. Trans. Amer. Soc. Agr. Eng. 42:403-409.

Else, M.A. and M.B. Jackson. 1998. Transport of 1-aminocyclopropane-1carboxylic acid (ACC) in the transpiration stream of tomato (Lycopersicon esculentum) in relation to foliar ethylene production and petiole epinasty. Aust. J. Plant Physiol. 25:453-458.

Else, M.A., K.C. Hall, G.M. Arnold, W.J. Davies, and M.B. Jackson. 1995. Export of abscisic acid, 1-aminocyclopropane-1carboxylic acid, phosphate and nitrate from roots to shoots of flooded tomato plants. Plant Physiol. 107:377-384.

Evans, R., J.W. Gilliamm, and W. Skaggs. 1996. Controlled drainage management guidelines for improving drainage water quality. North Carolina Coop. Ext. Serv. Publ. AG443. 18 Nov. 2008. <http:// www.bae.ncsu.edu/programs/extension/ evans/ag443.html .

Evans, R.O. and R.W. Skaggs. 1989. Design guidelines for water table management systems on coastal plain soils. Appl. Eng. Agr. 5:539-548.

Evans, R.O., J. Paul Lilley, R.W. Skaggs, and J.W. Gilliam. 2000. Rural land use, water movement, coastal water quality. North Carolina Coop. Ext. Serv. Publ. G605.

Evans, R.O., J.W. Gilliam, and R.W. Skaggs. 1990. Controlled drainage management guidelines for improving water quality. North Carolina Coop. Ext. Serv. Publ. AG443.

Faulkner, L.R. and W.J. Bolander. 1970. Agriculturally polluted irrigation water as a source of plant-parasitic nematode infestation. J. Nematol. 2:368-374.

Florida Department of Agriculture and Consumer Services. 2005. Gulf citrus BMP manual. Florida Dept. Agr. Consumer Serv., Tallahassee.

Florida Department of Agriculture and Consumer Services. 2008. Vegetable and agronomic crops BMP manual. Florida Dept. Agr. Consumer Serv, Tallahassee.

Ford, H.W. 1964. The effect of rootstock, soil type, and soil $\mathrm{pH}$ on citrus root growth in soil subject to flooding. Proc. Florida State Hort. Soc. 77:41-45.

Geraldson, C.M. 1977. Pepper production efficiency using the gradient-mulch concept. Proc. Florida State Hort. Soc. 90:385-388.

Gharbi, I., B. Ricard, D. Rolin, M. Maucourt, M.H. Andrieu, E. Bizid, S. Smiti, and R. Brouquisse. 2007. Effect of hexokinase activity on tomato root metabolism during prolonged hypoxia. Plant Cell Environ. 30:508517.

Gill, D.L. 1970. Pathogenic pythium from irrigation ponds. Plant Dis. Rptr. 54:1077-1079.

Gilliam, J.W. and R.W. Skaggs. 1986. Controlled agricultural drainage to maintain water quality. J. Irrig. Drain. Eng. 112:254-263.

Gilliam, J.W., R.W. Skaggs, and S.B. Weed. 1978. An evaluation of the potential for using drainage control to reduce nitrate loss from agricultural fields to surface waters. North Carolina State Univ., Water Resources Res. Inst. Rpt. No. 128.

Gilliam, J.W., R.W. Skaggs, and S.B. Weed. 1979. Drainage control to diminish nitrate loss from agricultural fields. J. Environ. Qual. 8:137-142.

Hanlon, E.A., G. Liu, and Y. Li. 2007. Literature review on calcium carbonate biogeochemistry and its effects on phosphorus removal in natural and constructed wetlands. Technical Rpt., Everglades Div., South Florida Water Management District, West Palm Beach, FL.

Harris, W.G., R.D. Rhue, G. Kidder, R.B. Brown, and R. Littell. 1996. Phosphorus retention as related to morphology and taxonomy of sandy coastal plain soil materials. Soil Sci. Soc. Amer. J. 60:15131521 .

Hendricks, G.S., S. Shukla, K.E. Cushman, T.A. Obreza, F.M. Roka, K.M. Portier, and E.J. McAvoy. 2007. Florida watermelon production affected by water and nutrient management. HortTechnology 17:328-335.

Henry, J.A. 1998. Weather and climate, p. 16-37. In: E.A. Fernald and E.D. Purdum (eds.). Water resources atlas of Florida. Inst. Sci. Public Affairs, Florida State Univ, Tallahassee.

Hodges, A., E. Philippakos, D. Mulkey, T. Spreen, and R. Muraro. 2006. Economic impact of Florida's citrus industry. Univ. Florida, Inst. Food Agr. Sci., Coop. Ext. Publ. FE 633. 11 Nov. 2008. <http:// edis.ifas.ufl.edu/FE633>.

Hubbell, J.N., R.D. William, S.M. Lin, Y.S.C. Roan, and H.A. Hsu. 1979. Effect of excessive water, cultivar and compost 
on performance of tomato production on two soil types, p. 154-175. In: R. Cowell (ed.). 1st Intl. Symp. Trop. Tomato, Asian Vegetable Res. and Dev. Ctr., Shanhua, Taiwan.

Jaber, F.H. and S. Shukla. 2004. Simulating water dynamics in agricultural stormwater impoundments for irrigation water supply. Trans. Amer. Soc. Agr. Eng. 47: 1465-1476.

Jaber, F.H., S. Shukla, and S. Srivastava. 2006. Recharge, upflux and water table response for shallow water table conditions. Hydrol. Process. 20:1895-1907.

Kalita, P.K. and R.S. Kanwar. 1993. Effect of water table management practices on the transport of nitrate- $\mathrm{N}$ to shallow groundwater. Trans. Amer. Soc. Agr. Eng. 36:413-422.

Karlen, D.L., R.E. Sojka, and M.L. Robbins. 1983. Influence of excess soil-water and $\mathrm{N}$ rates on leaf diffusive resistance and storage quality of tomato fruit. Commun. Soil Sci. Plant Anal. 14:699-708.

Kliewer, B.A. and J.W. Gilliam. 1995. Water table management effects on denitrification and nitrous oxide evolution. Soil Sci. Soc. Amer. J. 95:1694-1701.

Kozlowski, T.T. 2002. Acclimation and adaptive responses of woody plants to environmental stresses. Bot. Rev. 68:270-334.

Kuo, C.G. and B.W. Chen. 1980. Physiological responses of tomato cultivars to flooding. J. Amer. Soc. Hort. Sci. 195: $751-755$.

Kuo, C.G., J.S. Tsay, B.W. Chen, and P.Y. Lin. 1982. Screening for flooding tolerance in the genus Lycopersicon. HortScience 17:76-78.

Lalonde, V., C.A. Madramootoo, L. Trenholm, and R.S. Broughton. 1996. Effects of controlled drainage on nitrate concentrations in subsurface drain discharge. Agr. Water Mgt. 29:187-199.

Lanier, A.L. 1990. Database for evaluating the water quality effectiveness of best management practices. Dept. Biol. Agr. Eng., North Carolina State Univ., Raleigh.

Li, H., J.P. Syvertsen, R.J. Stuart, C.W. McCoy, A.W. Schumann, and W.S. Castle. 2004. Soil liming and flooding effects on diaprepres root weevil larval survival and citrus seedling growth. Proc. Florida State Hort. Soc. 117:157-162.

Liaghat, A. and S.O. Prasher. 1997. Role of soil and grass strips in reducing nitrate$\mathrm{N}$ pollution in subsurface-drained farmlands: Lysimeter results. Can. Water Resour. J. 22:117-127.

Lim, T.T., D.R. Edwards, S.R. Workman, B.T. Larson, and L. Dunn. 1998. Vege- tated filter strip removal of cattle manure constituents in runoff. Trans. Amer. Soc. Agr. Eng. 41:1375-1381.

Maas, P.W.T. 1987. Physical methods and quarantine, p. 265-291. In: R.H. Brown and B.R. Kerry (eds.). Principles and practice of nematode control in crops. Academic Press, Orlando, FL.

MacDonald, J.D., M.S. Ali-Shtayeh, J. Kabashima, and J. Stites. 1994. Occurrence of Phytophthora spp. in recirculated nursery irrigation effluents. Plant Dis. 78:607-611.

Magette, W.L., R.B. Brinsfield, R.E. Palmer, and J.D. Wood. 1989. Nutrient and sediment removal by vegetated filter Strips. Trans. Amer. Soc. Agr. Eng. 32:663-667.

Main, M.B. and G.M. Allen. 2007. Seasonal and habitat influences of avifauna of an agricultural impoundment in southwest Florida: Results of a five-year monitoring program. Fla. Sci. 70:219-240.

McIntosh, D.L. 1966. The occurrence of Phytophthora spp. in irrigation systems in British Columbia. Can. J. Bot. 44:15911596.

McNamara, S.T. and C.A. Mitchell. 1989. Differential flood stress resistance of two tomato genotypes. J. Amer. Soc. Hort. Sci. 114:976-980.

Mebalds, M., A. van der Linden, M. Bankier, and D. Beardsell. 1996. Using ultraviolet radiation and chlorine dioxide to control fungal plant pathogens in water. Nurs. Pap. 5:1-2.

Morgan, K.T., T.A. Obreza, and J.M.S Scholberg. 2007. Orange tree fibrous root length distribution in space and time. J. Amer. Soc. Hort. Sci. 132:262269.

Mossa, J. 1998. Surface water, p. 64-81. In: E.A. Fernald and E.D. Purdum (eds.). Water resources atlas of Florida. Inst. Sci. Public Affairs. Florida State Univ. Tallahassee.

O'Connor, G.A., H.A. Elliott, and R.K. Bastian. 2008. Degraded water reuse: An overview. J. Environ. Qual. 37:S-157-S-168.

Obreza, T.A. and B.J. Boman. 1992. Simulated citrus water use from shallow groundwater, p. 177-182. In: E.T. Engman (ed.). Irrigation and drainage: Saving a threatened resource - in search of solutions. Amer. Soc. Civil Eng., New York.

Olson, S.M. and E. Simonne. 2007. Vegetable production handbook for Florida. Vance Publishing, Lenexa, KS.

Oregon Department of Agriculture. 2003. A case study of small sediment basins to control irrigation-induced ero- sion in willow creek, Malheur County. 14 Nov. 2008. <http://egov.oregon. gov/ODA/NRD/docs/pdf/water/ sdmnt_basins.pdf>.

Overman, A.R. and T. Schanze. 1985. Runoff water quality from wastewater irrigation. Trans. Amer. Soc. Agr. Eng. 28:1535-1538.

Pandey, C., S. Shukla, and T.A. Obreza. 2007. Development and evaluation of soil moisture based seepage irrigation management for water use and quality. J. Irrig. Drain. Eng. 133(5):1-9.

Pathak, C.S. 2001. Frequency analysis of daily rainfall maxima for central and south Florida. Tech. Publ. EMA390. South Florida Water Management District, West Palm Beach, FL.

Pfister-Sieber, M. and R. Brandle. 1995. Response of potato tubers to hypoxia followed by re-aeration. Potato Res. 38:231-239.

Poysa, V.W., C.S. Tan, and J.A. Stone. 1987. Flooding stress and the root development of several tomato genotypes. HortScience 22:24-26.

Rao, R. and Y. Li. 2003. Management of flooding effects on growth of vegetable and selected field crops. Hort Technology 13:610-616.

Roberts, P.D., R.R. Urs, R.D. FrenchMonar, M.S. Hoffine, T.E. Seijo, and R.J. McGovern. 2005. Survival and recovery of Phytophthora capsici and oomycetes in tailwater and soil from vegetable fields in Florida. Ann. Appl. Biol. 146:351359.

Ruiz-Sanchez, M.C., R.D. Domingo, D. Morales, and A. Torrecillas. 1996. Water relations of Fino lemon plants on two rootstock under flooded conditions. Plant Sci. 120:119-125.

Schaffer, B., P.C. Andersen, and R.C. Poetz. 1993. Responses of fruit crops to flooding. Hort. Rev. (Amer. Soc. Hort. Sci.) 13:257-313.

Schueler, T. 1987. Controlling urban runoff: A practical manual for planning and designing urban BMPs. Metropolitan Washington Council of Governments, Washington, DC.

Schuster, M. 1959. Relation of root-knot nematodes in irrigation water to the incidence and dissemination of bacterial wilt of bean. Plant Dis. Rptr. 43:27-32

Schwer, C.B. and J.C. Clausen. 1989. Vegetative filter treatment of dairy milkhouse wastewater. J. Environ. Qual. 18: 446-451

Shukla, S. 2006. Harvesting water as a second crop. Citrus Veg. Mag. 70(9):28. 
Shukla, S. and C. Pandey. 2008. Impacts of organic amendments on soil water retention and water conservation in southwest Florida. Rpt. No. WRP-CO-08. Southwest Florida Water Management District, Brookesville, FL.

Shukla, S. and F.H. Jaber. 2002. Hydrologic/hydraulic modeling of citrus grove impoundment. Final Rpt. WRP-003. South Florida Water Management District, Fort Myers, FL.

Shukla, S. and F.H. Jaber. 2006. Stormwater as an alternative source of water supply: Feasibility and implications of watershed management. Univ. Florida, Inst. Food Agr. Sci. Ext. Publ. AE398. 18 Nov. 2008. <http://edis.ifas.ufl.edu/ AE398>.

Shukla, S. and S.D. Collins. 2005. Utilizing in-situ mesocoms to quantify phosphorus fluxes in the agricultural canals in the Lake Okeechobee basin. 3rd Intl. Congr. Chem. Environ., Indore, India.

Shukla, S., E.A. Hanlon, T. Borisova, F.M. Roka, M.B. Main, and P.D. Roberts. 2008. Watershed-scale impacts of using stormwater impoundments as an alternate source of water supply. Proc. 2008 Greater Everglades Ecosystem Restoration (GEER): Planning, Policy Sci. Conf., Naples, FL. p. 398-399.

Shukla, S., S.D. Collins, and K.L. Campbell. 2006. Effects of water retention in agricultural canals on phosphorus flux in the Lake Okeechobee basin. Amer. Soc. Agr. Eng., Annu. Intl. Mtg., Portland, OR.

Sieber, M. and R. Brandle. 1991. Energy metabolism in rhizomes of Acorus calamus and in tubers of Solanum tuberosum with regard to their anoxia tolerance. Bot. Acta 104:279-282.

Skaggs, R.W. and G.M. Chescheir. 2003. Effects of subsurface drain depth on nitrogen losses from drained lands. Trans. Amer. Soc. Agr. Eng. 46:237-244.
Skaggs, R.W. and J.W. Gilliam. 1981. Effect of drainage system design and operation on nitrate transport. Trans. Amer. Soc. Agr. Eng. 24:929-934.

South Florida Water Management District. 2007. Environmental resource permit information manual, Volume IV. 14 Nov. 2008. <http://www.swfwmd.state. fl.us/permits/erp/\#manual>.

Stanley, C.D. and G.A. Clark. 2003. Effects of reduced water table and fertility effects on subirrigated tomato production in southwest Florida. Univ. Florida. Inst. Food Agr. Sci. Ext. Publ. SS-429. 16 Nov. 2008. <http://edis.ifas.ufl.edu/SS429>.

Stevens, T., A. Hodges, and D. Mulkey. 2003. Florida agriculture and the vegetable industry. Inst. Food Agr. Sci., Food Resource Econ. Dept., Univ. Florida, Gainesville.

Stover, R.H. 1979. Flooding of soil for disease control, p. 19-28. In: C.J. Mulder (ed.). Soil disinfestation. Elsevier, Amsterdam, The Netherlands.

Syvertsen, J.P., R.M. Zablotowicz, and M.L. Smith, Jr. 1983. Soil temperature and flooding effects on two species of citrus. I. Plant growth and hydraulic conductivity. Plant Soil 72:3-12.

Thompson, D.L. 1965. Control of bacterial stalk rot of corn by chlorination of water in sprinkler irrigation. Crop Sci. 5:369-370.

U.S. Department of Agriculture. 1988. Handbook of conservation practices. Supplement. Soil Conservation Serv., U.S. Dept. of Agr., Washington, D.C.

U.S. Department of Agriculture. 2002. Census of agriculture-state data. Natl. Agr. Stat. Serv., U.S. Dept. Agr, Washington, DC.

U.S. Department of Agriculture. 2007. Census of agriculture-state data. Natl. Agr. Stat. Serv., U.S. Dept. Agr, Washington, DC.
U.S. Environmental Protection Agency. 1999. Wet detention ponds. EPA 832-F99-048. 18 Nov. 2008. <http://www.epa. gov/owm/mtb/wetdtnpn.pdf>.

U.S. Environmental Protection Agency. 2008. Management measure for protection of wetlands and riparian areas. 13 Nov. 2008. <http://www.epa.gov/ owow/nps/MMGI/Chapter7/ch72c.html>.

VanArman, J., W. Park, P. Nicholas, P. Strayer, A. McLean, B. Rosen, and J. Gross. 1998. South Florida Water Management District, p. 238-259. In: E.A. Fernald and E.D. Purdum (eds.). Water resources atlas of Florida. Inst. Sci. Public Affairs. Florida State Univ., Tallahassee.

Vartapetian, B.B. and M.B. Jackson. 1997. Plant adaptations to anaerobic stress. Ann. Bot. (Lond.) 79:3-20.

Vartapetian, B.B., I.N. Andreeva, I.P. Generozova, L.I. Polyakova, I.P. Maslova, Y.I. Dolgikh, and A.U. Stepanova. 2003. Functional electron microscopy in studies of plant response and adaptation to anaerobic stress. Ann. Bot. (Lond.) 91:155-172.

Whiteside, J.O. and T.W. Oswalt. 1973. An unusual brown rot outbreak in Florida citrus grove following sprinkler with Phytophthora-infested water. Plant Dis. Rptr. 57:391-393.

Winsberg, M.D. 2003. Florida weather. University Press of Florida, Gainesville, FL.

Yetisir, H., M.E. Caliskan, S. Soylu, and M. Sakar. 2005. Some physiological and growth responses of water melon [Citrullus lanatus (Thunb.) Matsum. And Nakai] grafted onto Lagenarea siceraria to flooding. Environ. Exp. Bot. 58:1-8.

Young, R.A., T. Huntrods, and W. Anderson. 1980. Effectiveness of vegetated buffer strips in controlling pollution and feedlot runoff. J. Environ. Qual. 9: 483-487. 